\title{
Política e História no Pensamento de Montesquieu
}

\section{Renato Moscateli ${ }^{1}$}

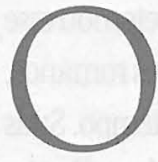

tempo muitas vezes faz com que certas investidas de um pensador pelos múltiplos caminhos do saber acabem sendo relegadas a um segundo plano, permanecendo amplamente conhecidas apenas aquelas trilhas que the garantiram a fama nos domínios da História Intelectual. No século XVIII podem ser encontrados vários exemplos. Voltaire (1694-1778), tornou-se célebre por suas obras literárias, sobretudo pelos contos filosóficos, mas foi também um dos mais importantes historiadores da época, graças a textos como O Século de Luís XIV, o Ensaio sobre os costumes e a História de Carlos XII. O escocês David Hume (1711-1776), cuja contribuição à filosofia, especialmente no campo da teoria do conhecimento, não pode ser ainda hoje subestimada, dedicou-se igualmente a escrever uma História da Inglaterra em quatro volumes. Ao lado deles, houve um escritor que ganhou renome de grande pensador político por ter estabelecido princípios que fundamentariam as constituições de inúmeros Estados modernos: Charles-Louis de Secondat, o Barão de La Brède e de Montesquieu (1689-1755), ilustre autor de 0 espirito das leis. ${ }^{2}$ Assim como eles, Montesquieu também nutriu uma grande estima pela História, o que o levou a utilizá-la amplamente em sua obra-prima sobre política, bem como a escrever um pouco conhecido - porém excelente - estudo histórico sobre Roma: as Considerações sobre as causas da grandeza dos romanos e de sua decadência. Deste modo, tendo a História desempenhado um papel tão significativo, ainda que não suficientemente lembrado, nas reflexões do autor francês, 0 presente texto, imbuído do interesse sobre a atividade do Montesquieu historiador, explorará algumas de suas características mais importantes, a fim de que os leitores que se iniciam na leitura de suas obras possam conhecê-la melhor e, quem sabe, apreciá-la com a mesma reverência devida à sua grande obra política.

Mestre em História pelo Programa Associado UEM/UEL. Autor de O Senbor das Letras: o Antigo Regime e a Modernidade Voltairiana. Maringá: Eduem, 2000.

2 Montesquieu. Do espírito das leis. São Paulo: Abril Cultural, 1973. (0s Pensadores). 


\section{Uma ‘História-problema’ da CivilizaÇão Romana}

Como é possível a um povo sobressair-se em meio aos outros que o circundam, elevar-se ao trono do mundo conhecido, inspirar em seus inimigos um grande medo mesclado a respeito e admiração, unicamente para, após atingir um auge glorioso, perder seu vigor e sua autoridade diante das nações, sendo subjugado por uma infinidade de adversários? Tal questão, quando aplicada à história dos romanos, vem intrigando autores desde a própria época em que Roma estava somente começando a declinar, e diversas foram as respostas apresentadas. ${ }^{3}$ No Século das Luzes, Montesquieu retomou esse antigo debate para esclarecer as razões tanto do poderio quanto da fraqueza dos romanos, e com esse intuito escreveu um dos mais interessantes textos históricos de seu tempo. Suas Considerações sobre as causas da grandeza dos romanos e de sua decadência, publicadas em 1734, demonstram um vivo empenho do autor em compreender a história de Roma não como uma sucessão de eventos ligados apenas superficialmente, mas como um movimento de ascensão e queda cuja trajetória possui contornos bem definidos que podem ser desvendados pelo olhar atento e meticuloso do historiador. Assim, o trabalho de Montesquieu não se limita a assinalar o papel que um determinado evento ou um certo personagem em especial desempenhou no desenrolar da história romana; ele é marcado por uma abordagem globalizante, que quer dimensionar corretamente os acontecimentos em relação ao conjunto das causas profundas que levaram Roma a ser 0 que foi. Tal perspectiva constitui uma característica essencial do pensamento histórico de Montesquieu e revela sua modernidade, pois aponta para duas tendências que se tornariam cada vez mais dominantes na produção historiográfica dos séculos seguintes: a busca por escrever uma História capaz de interpretar os eventos ao invés de apenas narrá-los - uma História dos processos, das conjunturas e das estruturas -, e o estabelecimento de problematizações como princípio para a pesquisa histórica - a "História-problema", no dizer da Escola dos Annales.

Por outro lado, forçoso é reconhecer que Montesquieu optou por tecer suas Considerações recorrendo a um campo pouco original à primeira vista, ou seja, a História política, algo que poderia ofuscar a modernidade de sua obra, ligando-a à produção histórica ainda preponderante em sua época. Certamente, uma parte considerável das questões abordadas por Montesquieu possui um cunho político, tratando-se de guerras, sucessões governamentais e conflitos entre membros do Estado, como senadores, cônsules,

3 Para uma análise a respeito de como os contemporâneos de Roma enxergaram seu próprio tempo, ver: MAzzarino,

S. O fim do mundo antigo. São Paulo: Martins Fontes, 1991. 
pretores e imperadores. Todavia, e apesar disso, não é correto incluir as Considerações no rol das crônicas que se resumem a fazer uma lista dos principais fatos políticos de um determinado período. Montesquieu consegue enxergar as relações existentes entre esses eventos, mostrando que eles fizeram parte de tendências que se manifestaram a médio e longo prazos na história de Roma, as quais determinaram o sucesso ou o fracasso das iniciativas tomadas por seus cidadãos. Com isso, o autor ultrapassou os horizontes da "História-batalha" tão criticada pelos pesquisadores do presente. Ainda que as Considerações não tenham uma abordagem tão ampla como a dos textos históricos de Voltaire, por exemplo, ao se propor a investigar as causas que levaram os romanos à grandeza e à posterior decadência, elas também devem ser incluídas entre as grandes obras históricas do Iluminismo.

Sendo assim, cabe perguntar: para Montesquieu, quais são, afinal, as causas da grandeza de Roma? Logo de início, o historiador salienta uma peculiaridade que teria sido fundamental para que o povo romano se tornasse tão poderoso: segundo ele, Roma já nasceu uma cidade conquistadora, cujos habitantes tinham a guerra como sua meta principal. Dotados de uma belicosidade que se transmitia de geração a geração sem perder seu vigor, os romanos jamais se cansavam de levar o combate até seus adversários. Durante séculos e após centenas de batalhas, eles incorporaram a disciplina militar em suas vidas e desenvolveram a arte da guerra como nenhum outro povo. Primeiro na Itália, depois nas regiões vizinhas, as legiões de Roma deixaram claro para os outros Estados que eles jamais deveriam permanecer tranqüilos ou seriam subjugados. A guerra era tão prezada pelos romanos que, mesmo quando alcançavam a vitória, eles impunham aos inimigos condições de paz que cedo ou tarde se tornavam intoleráveis, de forma que o conflito não tardava a eclodir novamente. Se eram derrotados, ao invés de se deixar abater, os romanos aumentavam suas pretensões, o que não apenas constrangia os adversários como também atribuía aos próprios romanos uma necessidade ainda maior de vencer. Física e espiritualmente, os cidadãos de Roma se formaram aliando as qualidades guerreiras a uma maneira peculiar de compreender a si mesmos como indivíduos e como parte da sociedade: "Estando sempre expostos às mais aterradoras vinganças, a constância e a valentia tornaram-se-lhes necessárias, e neles essas virtudes não se distinguiam do amor-próprio, do amor à família, à pátria e a tudo o que há de mais precioso entre os homens". 4

MonTESQuieu. Considerações sobre as causas da grandeza dos romanos e de sua decadência. Rio de Janeiro: Contraponto, 2002. p. 14 
Essa descrição das virtudes romanas é muito importante para se entender as causas da grandeza de Roma, segundo Montesquieu. De fato, 0 autor acredita que nos primeiros séculos de sua história os romanos foram bem-sucedidos nas tarefas que impuseram a si mesmos porque estavam animados por um espírito adequado a seus objetivos. Neles, o desejo de vencer se sobrepunha ao apego pelas riquezas que as vitórias podiam trazer. Para impedir a corrupção moral que a acumulação de bens materiais certamente acarretaria, os governantes distribuíam eqüitativamente as terras conquistadas entre os cidadãos. Assim, Montesquieu aponta a pobreza dos romanos como um elemento crucial de seu poderio, pobreza que os forçava a lutar constantemente em busca de novos butins. Para dimensionar corretamente o papel desempenhado pelos costumes austeros nas vitórias de Roma, Montesquieu comparaos aos da sua grande adversária: Cartago. Segundo o autor, a opulência dos cartagineses não era um ponto positivo em relação à pobreza dos romanos. Muito pelo contrário, nesse caso Roma possuía uma vantagem crucial, pois as riquezas materiais podiam ser consumidas, mas as virtudes dos romanos não se acabavam. Eles possuíam uma ambição sem limites, motivados pelo orgulho e pelo desejo de comandar. Por essas razões, Cartago foi incapaz de vencer Roma:

Batalhas perdidas, a diminuição do povo, o enfraquecimento do comércio, 0 esgotamento do Tesouro público e a sublevação das nações vizinhas podiam obrigar Cartago a aceitar as mais duras condições de paz. Roma, no entanto, não se conduzia pelo sentimento dos benefícios e dos malefícios: determinava-se tão-somente por sua glória. Como não imaginava poder existir se não dominasse, não havia esperança nem temor capaz de obrigá-la a fazer uma paz que não fosse imposta por ela. ${ }^{5}$

Inicialmente governada por reis, Roma não tardou a adotar o regime republicano, no qual a plebe pôde participar tanto quanto os patrícios por meio da eleição de seus magistrados. Tal mudança política deu aos romanos um governo que se coadunava ainda mais com os valores morais em que estavam baseados os seus costumes, instigando neles um grande amor à liberdade. Por isso, Montesquieu salienta que a grandeza obtida pela república romana estava baseada na virtude de seus cidadãos, um tema que o autor retomaria mais tarde em 0 espirito das leis: "Não há nada tão poderoso quanto uma República em que as leis são observadas não por medo, nem tampouco pela razão, mas por paixão, como se deu em Roma e na Lacedemônia: é que, nesse caso, junta-se à 
sabedoria de um bom governo toda a força que uma facção poderia ter". ${ }^{6}$ Esse governo sábio instituiu até mesmo uma magistratura especialmente destinada a velar pela manutenção dessas boas paixões: era a dos censores, que vigiavam os cidadãos para prevenir e corrigir os abusos dos costumes, agindo onde os outros magistrados não podiam, e fazendo com que a austeridade das maneiras não fosse abalada.

Seguramente, Montesquieu não pretende transmitir a imagem de uma Roma tão virtuosa cujos cidadãos viveriam em perfeita concórdia entre si. Pelo contrário, ele descreve as constantes disputas internas que animaram a sociedade romana, opondo patrícios e plebeus em diversos momentos. Entretanto, o autor diz que tais conflitos também contribuíram para a grandeza de Roma, na medida em que conservavam seus cidadãos em um estado de agitação que se mantinha mesmo em tempos de paz, garantindo que seu espírito belicoso não adormecesse. Afinal, para Montesquieu, "em um Estado livre, exigir pessoas destemidas na guerra e tímidas na paz é desejar o impossível. Em regra, sempre que vemos toda a população tranqüila em um Estado que dá a si mesmo 0 nome de República, podemos ter certeza de que nele não existe liberdade". ' Se haviam muitas divergências entre os grupos sociais que compunham a república romana, isto na verdade levava a uma harmonia resultante da própria diversidade.

Graças a todos esses fatores, Roma tornou-se a soberana das nações com as quais se defrontou. No entanto, tamanha grandeza estava fadada a desmoronar, não devido aos inimigos externos que fomentara, mas por causa de suas próprias falhas. Montesquieu apresenta uma interpretação muito perspicaz da decadência de Roma que antecipa, sob certos aspectos, a concepção dialética da História formulada por autores do século XIX. Para ele, os romanos foram um povo talhado para uma existência de expansão contínua, de conquistas e vitórias, e suas leis e costumes eram adequados para esse estilo de vida. Porém, quando Roma viu-se todo-poderosa, quando seus inimigos estavam a seus pés, enfim, quando sua obra estava concluída, ela foi incapaz de manter sua liberdade, pois necessitava modificar seu próprio espírito para acomodar-se à sua nova condição, e as transformações que realizou serviram apenas para enfraquecê-la e lançá-la gradativamente na servidão. Assim, uma série de mudanças, nascidas do próprio desenvolvimento das instituições romanas, provocou sua queda. Se anteriormente as divisões internas fortaleciam a harmonia do Estado, o crescimento dele fez com que tais divisões se tornassem grandes demais para serem controladas. Se a pobreza havia dado aos romanos uma austeridade nos costumes que era indispensável para a manutenção da república, os imensos tesouros

6 Id. ib., p. 29.

Id. ib., p. 74. 
trazidos pelas conquistas de seus exércitos acabaram finalmente por corromper os cidadãos e arruinar suas virtudes. Quanto mais extensas e longínquas se encontravam as fronteiras dos domínios de Roma, mais crescia o poder dos generais, que assumiam diante de suas legiões o papel de liderança que os governantes deveriam exercer. Admirados com os privilégios desfrutados pelos cidadãos romanos, muitos dentre os povos por eles conquistados exigiram e conseguiram a mesma cidadania, destruindo desse modo a coesão de Roma: a incorporação dos estrangeiros extinguiu aqueles sentimentos romanos e aquela unidade de espírito que, nas palavras de Montesquieu, manifestavam-se no ódio à tirania e no amor à liberdade, à igualdade e à pátria.

Tais foram as causas que paulatinamente minaram as forças de Roma. A primeira grande conseqüência foi o fim da liberdade republicana e a instauração do governo imperial. Antecipando a discussão que faria mais tarde em 0 espirito das leis, Montesquieu afirma em suas Consider ações que a separação dos poderes tinha sido essencial para o sucesso da república, assim como foi sua concentração que permitiu o surgimento da tirania dos imperadores. Estes tomaram em suas mãos as magistraturas mais importantes, retirando do povo e do senado o direito de eleger seus representantes. A fim de evitar o descontentamento resultante dessa atitude, os imperadores souberam acentuar a corrupção do povo: compraram a sua liberdade em troca de dinheiro, de ócio e de espetáculos. Uma vez que não participava mais da política e da guerra como antes, a plebe romana se comprazia em dedicar-se às coisas mais fúteis e mais vis. Embora as conquistas militares não tenham acabado durante o império, suas glórias e seus benefícios não serviam mais ao engrandecimento do povo romano. Do mesmo modo como fora nocivo para a república, o crescimento do território também foi determinante para a queda do império. Quanto mais exércitos eram necessários para defender os domínios, maior era o número de generais desejosos de poder que lutavam entre si pelo controle do império e interferiam na sucessão governamental. Isto enfraqueceu Roma e impediu que ela conseguisse resistir aos ataques dos bárbaros que passaram a assolar o império em seus últimos séculos. Segundo Montesquieu, "não foi uma determinada invasão que destruiu o império, mas todas as invasões". ${ }^{8}$ Os bárbaros possuíam vigor e virtudes semelhantes àquelas que haviam animado os romanos em seus primeiros tempos, de forma que suas investidas constantes não puderam ser devidamente rechaçadas pelos exércitos imperiais. Nem mesmo a estratégica divisão do império em dois pôde salvar Roma de sua queda. E, ainda que a porção oriental do império

8 Id. ib., p. 158. 
tenha sobrevivido por mais mil anos, ela continuou a ser abalada por dificuldades muito parecidas com as que destruíram sua parcela ocidental, às quais se juntaram os distúrbios internos motivados pelo cristianismo, que se tornara sua religião oficial. Também o império de Constantinopla ruiu por suas próprias deficiências.

Desta maneira, Montesquieu apresenta a cadeia de eventos que produziu a grandeza de Roma e sua conseqüente decadência. Como sua exposição deixa claro, tais eventos não se deram aleatoriamente, mas se uniram em uma teia de causas essenciais. Por meio da investigação sobre os caminhos trilhados pelos romanos, o autor enunciou algumas das idéias fundamentais de seu pensamento histórico. Para ele,

Não é a sorte que domina o mundo. Podemos perguntá-lo aos romanos, que tiveram uma sucessão contínua de situações ditosas, enquanto se governaram em um certo plano, e uma sucessão ininterrupta de reveses, quando se conduziram com base em outro. Existem causas gerais, seja morais, seja físicas, que atuam em cada monarquia, elevam-na, sustentam-na ou the impõem a derrocada; todos os acidentes estão sujeitos a essas causas. Quando o acaso de uma batalha, isto é, uma causa particular, destrói um Estado, é porque havia uma causa geral que fazia com que esse Estado devesse perecer em uma única batalha. Em uma palavra, o rumo principal arrasta consigo todos os acidentes particulares. ${ }^{9}$

Salientando o papel proeminente das causas gerais nos rumos da história, Montesquieu antecipou em suas Considerações aquilo que seria o cerne de sua obra-prima: 0 espirito das leis, publicado em 1748, não apenas buscaria desvendar as causas gerais do desenvolvimento de um determinado povo em particular, mas de todo e qualquer Estado, por meio de um monumental esforço para distinguir o espírito que anima a cada um deles.

\section{Novas Bases TeÓRICO-METODOLÓGICAS PARA OS Estudos HistóRICOS}

No século XVII, os fundadores do jusnaturalismo (Grotius, Hobbes, Locke e Pufendorf, entre outros) estabeleceram as bases da reflexão política que homens como Montesquieu, Rousseau e Kant iriam depois continuar. Segundo Norberto Bobbio, os jusnaturalistas empreenderam "a construção de uma ética racional, separada

9 Id. ib., pp. 149-150. 
definitivamente da teologia e capaz por si mesma, precisamente porque fundada finalmente numa análise e numa crítica racional dos fundamentos, de garantir - bem mais do que a teologia, envolvida em contrastes de opiniões insolúveis - a universalidade dos princípios da conduta humana" ${ }^{10}$ Portanto, 0 jusnaturalismo tornou a razão 0 instrumento principal para se lidar com as questões éticas e jurídicas, e, ao mesmo tempo, também o fiel da balança dos valores morais, constituindo uma corrente de pensamento que o Iluminismo iria herdar e fazer prosperar.

Seguindo essa tendência, Montesquieu inicia 0 espirito das leis oferecendo uma definição basilar para a arquitetura de sua obra: "as leis, no seu sentido mais amplo, são relações necessárias que derivam da natureza das coisas". ${ }^{11}$ A partir dessa definição, conclui que antes mesmo de haver leis feitas pelos homens, existiam relações de justiça possíveis. Em outras palavras, Montesquieu defende a idéia de que, para além da multiplicidade dos códigos legais criados pelas diferentes civilizações ao longo da historia, existem certas leis dotadas de uma validade $a$ priori porque são relações imanentes a determinadas configurações de elementos que não precisam necessariamente manifestar-se no mundo empírico -, da mesma forma como a soma dos ângulos internos de um triângulo qualquer é sempre de $180^{\circ}$, ou, para citar o exemplo dado pelo próprio autor, como um círculo, antes mesmo de ser traçado, deve ter todos os seus raios de igual comprimento. Essas propriedades matemáticas são inerentes à natureza do círculo e do triângulo, quer eles existam ou não no mundo físico, pois estão contidas nas próprias idéias de círculo e de triângulo. Se isso é correto em se tratando de entidades matemáticas, Montesquieu entende que o mesmo se verifica no tocante ao universo jurídico, ou pelo menos no domínio das relações derivadas da natureza das coisas, as quais têm de ser, sem dúvida, invariáveis.

Com efeito, a fundamentação em tais princípios levou Montesquieu a vislumbrar certos aspectos da história por meio de uma perspectiva até então não muito comum. Em sua obra mais importante, o autor buscou compreender uma série de eventos e de processos históricos tendo a reflexão política como fio de Ariadne, considerando as instituições e as leis criadas desde os gregos e os romanos da Antigüidade até as estabelecidas por ingleses e franceses em sua própria época. Em princípio, essa abordagem talvez não parecesse ser inovadora, uma vez que muitos

${ }^{10}$ Bobвio, N.; Bovero, M. Sociedade e Estado na filosofia política moderna. São Paulo: Brasiliense, 1987. p. 17.

11 Montesquieu. 2002, Op. cit., p.33. 
outros autores, tais como Platão, Aristóteles, Políbio, Maquiavel e Vico, já haviam feito algo de semelhante no passado ${ }^{12}$. Entretanto, se Montesquieu realiza um trabalho similar ao desses outros grandes nomes da História Intelectual, na medida em que também fornece uma tipologia dos governos, ele acrescenta algo de original ao se propor a desvendar o que chama de espirito das leis e das instituições políticas. Neste sentido, o escopo de seu trabalho ultrapassa a simples classificação dos fenômenos políticos verificados no decorrer da história, e procura utilizar-se de um instrumental conceitual específico para lidar com o material fornecido pelas fontes históricas. Tal procedimento é mencionado pelo próprio Montesquieu no prefácio de sua principal obra. De sua leitura se apreende que, a partir de um exame inicial, o autor percebeu a existência de algo mais que o mero acaso ou a fatalidade cega guiando os passos da humanidade; em seguida, ele se serviu da razão no intuito de vislumbrar o encadeamento necessário entre esses passos, um encadeamento cuja lógica apresenta-se nas diretrizes às quais cada fato político tem de obedecer, não por uma imposição teórica arbitrária da parte de quem os investiga, mas porque os princípios conceituais colocados diante dos olhos do pesquisador correspondem ao espírito que anima os movimentos da história.

Assim, desejando decifrar o necessário oculto pela multiplicidade dos fenômenos do contingente, Montesquieu abstraiu o espírito das instituições jurídico-políticas conhecidas, ou seja, sua essência fundamental, pois ele acreditava que cada forma de organização política possuía uma natureza própria, independente das condições específicas e singulares de suas manifestações históricas. 0 autor propôs que existiam basicamente três tipos de governo, ou seja, o republicano, o monárquico e o despótico, cabendo a cada um deles um princípio específico do qual quanto mais se aproximassem os membros do corpo político, mais perfeita seria a ordem do governo. Na república tal princípio seria a virtude, enquanto na monarquia e no despotismo seriam a bonra e o medo, respectivamente. Para esclarecer os termos de seu estudo, Montesquieu define a natureza de um governo como sendo aquilo que o faz ser como é, ao passo que o princípio é definido como aquilo que faz o governo agir: "a primeira constitui sua estrutura particular e, a segunda, as paixões humanas que o movimentam". ${ }^{13}$ Ora, a proposição de uma tal taxonomia política, bem como de seus princípios correspondentes, constitui um passo importante no desenvolvimento teórico-metodológico dos estudos sobre as relações entre

${ }^{12}$ A este respeito ver: Boввіо, N. A teoria das formas de governo. Brasília: Editora UnB, 1997.

${ }^{13}$ Montesquieu. 2002, Op. cit., p. 49. 
Estado e sociedade. Segundo Ernst Cassirer, Montesquieu foi o primeiro pensador a utilizar claramente a noção de "tipo ideal histórico" "14, uma vez que 0 espírito das leis apresenta uma teoria política e sociológica dos tipos: "A obra quer mostrar e demonstrar que os organismos políticos que designamos pelos nomes de república, aristocracia, monarquia, despotismo não são meros agregados de elementos variados, que cada um dentre eles está, por assim dizer, pré-formado, e é a expressão de uma determinada estrutura". ${ }^{15}$ Para apreender a existência de tais estruturas, não basta observar a infinidade de fenômenos políticos e sociais que compõem o multifacetado espetáculo da história; é preciso concentrar-se nas linhas de força que conduzem as ações humanas com sua influência inexorável. Para Montesquieu, seépossível encontrar numerosos exemplos singulares de monarquias ao longo do tempo e do espaço, deve haver apenas uma estrutura básica, um tipo ideal de monarquia que pode ser concebido racionalmente e cujas características derivam não de quaisquer circunstâncias particulares, e sim da própria natureza de um Estado que é governado por um único indivíduo de acordo com leis fixas e estabelecidas. 0 mesmo ocorre em se tratando da república, cuja natureza é a de que o povolo tem 0 poder soberano, e do despotismo, cuja natureza étal que uma só pessoa governa guiandose apenas por sua vontade e seus caprichos. Como se pode perceber, a classificação política executada por Montesquieu leva em consideração dois critérios básicos: por um lado, quem governa (muitos ou um só), o que diferencia a república dos outros governos, e, por outro lado, como se governa (de acordo com leis fixas ou seguindo um arbítrio particular), predicado que separa a monarquia do despotismo.

$\mathrm{Na}$ investigação desenvolvida por Montesquieu, cada um desses tipos ideais configura-se como uma referência teórica necessária para trilhar com segurança os caminhos da História política das diferentes civilizações. Deve-se ressaltar que, ainda de acordo com Cassirer, o autor é consciente de que seus conceitos possuem uma natureza eminentemente lógica, não com o objetivo de representar a abstração da universalidade de um determinado gênero, ou mesmo de destacar os traços comuns visíveis nos fenômenos reais, mas com 0 intuito de estabelecer a generalidade e a universalidade de sentido presente nas formas particulares de Estado, tornando perceptível a regra imanente que rege essas formas. Sendo assim, não se deve esperar que os atributos dos tipos ideais de governo propostos por Montesquieu possam ser encontrados na íntegra em algum dos

\footnotetext{
14 Vale dizer que embora a noção de "tipo ideal" seja encontrada em 0 espírito das leis, a própria expressão "tipo ideal" não foi proposta por Montesquieu, sendo utilizada no presente estudo em sentido retrospectivo.

15 Cassirer, E. A filosofia do Iluminismo. Campinas: Editora da Unicamp, 1997. p. 283.

${ }^{16}$ É importante lembrar que Montesquieu distingue o governo do povo como um todo (república democrática) daquele no qual somente uma parte dele tem o poder (república aristocrática).
} 
casos históricos analisados em sua obra, algo que a leitura do livro revela logo. Entretanto, isto não significa que a ordem inerente aos arquétipos descritos pelo autor não tenha validade, pois, "ao atribuir às diversas formas de Estado um princípio específico, repousando a essência da república na virtude, a da monarquia na honra etc., ele não entende que se possa tomar essas essências por realidades empíricas concretas. Mais do que um ser, éum dever-ser (ein Sollen) o que elas exprimem. ${ }^{17}$

Por esses motivos, não é totalmente correto criticar Montesquieu dizendo que são muitos os casos em que as características que ele confere ao regime monárquico estão presentes em certos governos republicanos, ou que as realizações de determinados Estados despóticos conviriam melhor a uma monarquia tal como ele a descreve. Porém, desde a época em que Montesquieu publicou sua obra sobre os governos e as leis, muitos têm sido os que procuraram usar a própria História contra as teorias do autor. ${ }^{18}$ Ora, o que esses críticos de Montesquieu não viram com clareza foi justamente que o autor tinha em mente a caracterização ideal dos tipos de governo, e não simplesmente a exposição de qualidades que estariam sempre presentes nos casos históricos por ele mencionados e analisados, o que pode ser visto na afirmação que fecha o livro terceiro de 0 espírito das leis: "Tais são [a virtude, a honra e o medo] os princípios dos três governos, o que não significa que, em determinada república, se seja virtuoso, mas sim que se deveria sê-lo. Isso também não prova que, numa certa monarquia, a honra reine e que, num dado Estado despótico, o medo vigore; mas sim que a honra e o medo deveriam existir, sem 0 que o governo seria imperfeito". ${ }^{19}$ Imperfeito em que sentido? Considerando a configuração sócio-política de uma república democrática ideal, por exemplo, onde cada indivíduo é também um cidadão - e portanto um participante ativo da vida política -, onde a instituição da isonomia garante que todos devem se submeter da mesma forma e com o mesmo zelo ao poder da lei, nada mais necessário do que a preponderância de um atributo coletivo fundamental: a virtude política, que tem sua essência em sentimentos tais como "0 amor pelas leis e pela pátria", "a renúncia de si mesmo", "a orientação para o bem geral" e, acima de tudo, "o amor à igualdade". Todos esses sentimentos são as paixões humanas que fazem a república agir, como escreve Montesquieu. Entretanto, no final das contas são os homens que agem, e não um ser impessoal chamado Estado, e o que faz os homens agirem com mais eficiência não são

\footnotetext{
${ }^{17}$ CAsSiRer, E. Op. cit, p. 284.

${ }^{18}$ Para conhecer as objeções de um contemporâneo de Montesquieu, ver: VoltarRe. Comentários políticos. São Paulo: Martins Fontes, 2001.

19 Montesquieu. 2002, Op. cit., p. 55.
} 
códigos de leis impostos arbitrariamente, mas o conjunto de imperativos que cada um deles tem gravado em seus espíritos e que serve como guia de suas consciências. Assim sendo, sem a presença dessa virtude moral e ao mesmo tempo política descrita por Montesquieu, único princípio capaz de conferir a dinâmica adequada ao regime democrático, este restaria imperfeito: seria uma estrutura política puramente exterior aos indivíduos, os quais se sentiriam constrangidos à obediência apenas pela coerção externa da lei, e não pelo impulso autônomo de sua própria vontade. Sem a "mola" da virtude política, a máquina republicana permaneceria imóvel e em pouco tempo seu peso a faria ruir sob si mesma, como o exemplo de Roma deveria deixar bem claro.

Graças à utilização desses tipos ideais, Montesquieu pode ser considerado um importante precursor dos estudos científicos dos fatos humanos que se constituiriam em meados do século XIX, ${ }^{20}$ pois seu método foi não apenas adotado, mas desenvolvido em suas múltiplas possibilidades pelas ciências sociais a partir de então. ${ }^{21}$ Dentre os pesquisadores que prosseguiram com maior talento a trilha apontada por Montesquieu, encontra-se o pensador das ciências sociais Max Weber (1864-1920). Aqueles princípios teórico-metodológicos que o escritor francês havia apresentado implicitamente em sua obra, Weber transformou-os na peça-chave de seu arsenal conceitual. Por meio da formulação de tipos ideais, o sociólogo alemão expõe como se desenvolveria uma forma particular de ação social se o fizesse racionalmente em direção a um fim e se fosse orientada de forma a atingir um e somente um fim. Em se tratando de tipos complexos (formados por várias propriedades), sua construção assume a forma de síntese, a qual idealiza os fenômenos em uma articulação significativa de abstrações, constituindo uma "pauta de contrastação" que permite situar os fenômenos reais em sua relatividade. ${ }^{22}$ Ao mesmo tempo em que demonstra a herança de 0 espirito das leis presente no trabalho de Weber, esta descrição dos tipos ideais lança mais luz sobre o caráter da obra de Montesquieu. De fato, assim como os tipos ideais nas investigações feitas por Weber, a caracterização da natureza e dos princípios dos governos proposta por Montesquieu tem 0 papel de mostrar como um aspecto da realidade social, isto é, as diferentes formas de organização política, teria de "funcionar" se sua dinâmica ocorresse racionalmente visando a um objetivo específico, a saber, sua própria conservação. Nesse sentido, Montesquieu constrói seus conceitos para, em seguida, compará-los com as evidências

\footnotetext{
20 Tragtenberg, M. Apresentação. In: Weber, M. Textos selecionados. São Paulo: Nova Cultura, 1997. p. 5-15. (Os Economistas).

${ }^{21}$ Cassirer, E. Op. cit.

22 Tragtenberg, M. Op. cit.
} 
oferecidas pela história, não propriamente para comprovar que as repúblicas, as monarquias e os despotismos reais são casos empíricos dos modelos que ele idealiza, mas para visualizar até que ponto os movimentos dos Estados concretos aproximam-se ou afastam-se da racionalidade que deveria estruturá-los, permitindo ao autor, entre outras coisas, julgar se determinadas leis estabelecidas em um dado governo seriam ou não as mais eficazes e corretas tendo-se como referência as características do tipo ideal correspondente.

0 que se mostra fundamental em 0 espirito das leis é que essas características não devem existir isoladamente, mas se configuram em redes maiores de inter-relações de acordo com a natureza própria de cada governo. Foi afirmado que os tipos ideais complexos, ou seja, os que são compostos por um conjunto de propriedades distintas, são concebidos como uma articulação significativa de abstrações. Assim, pode-se dizer que a obra de Montesquieu é toda marcada pelo intuito de chamar a atenção para a amplitude dos vínculos naturais (lógicos) que têm de haver entre as múltiplas propriedades dos Estados e dos povos no que diz respeito ao espírito das leis que os regem. Segundo Cassirer, Montesquieu apresenta "a doutrina de que todos os elementos constitutivos de uma determinada sociedade estão entre si numa situação de estrita correlação. Não são as parcelas de uma soma e sim formas interdependentes cuja ação recíproca depende da forma do todo. Até nos mínimos detalhes verifica-se essa comunidade de ação e essa organização estrutural" ${ }^{23}$ Assim sendo, aspectos tais como a educação, as leis (criminais, civis, suntuárias, etc.), o luxo, a condição das mulheres, a maneira de fazer a guerra e a paz, os tributos, a geografia (clima e solo), a liberdade e a servidão, o comércio, o número de habitantes e a religião, todos eles compõem mosaicos cujas pequenas partes não estão colocadas arbitrariamente, mas obedecem a uma ordem específica dada pela natureza das coisas, isto é, pela constituição inerente a cada regime de governo. Eles formam, em síntese, totalidades históricas. Se o despotismo convém aos países quentes e a monarquia aos de clima temperado; se os Estados de grande extensão tendem ao regime despótico e os pequenos, ao regime republicano; se no governo de um só o comércio é baseado no luxo, e no governo de muitos é fundado na economia; enfim, se o islamismo é mais adequado aos governos despóticos e o cristianismo é mais apropriado aos governos moderados (o catolicismo às monarquias e o protestantismo às repúblicas), para Montesquieu tudo isto decorre das relações necessárias, possíveis de se depreender por meio do uso de instrumentos racionais no estudo da história. Em suma, o autor esforça-se para mostrar que a correta e profunda compreensão das realizações históricas das diferentes

${ }^{23}$ Cassirer, E. Op. cit., p. 285. 
nações não pode prescindir de uma teoria política capaz de desvendar, por sob o véu das contingências, uma imagem coerente das sociedades humanas.

\section{Uma História das Mudanças e das PermanênCias}

Uma vez que se tenha salientado a abordagem interpretativa presente nas Considerações, bem como o arsenal teórico-metodológico que sustenta a visão histórica de 0 espirito das leis, é possível interligá-los para lidar com uma questão central na avaliação da obra de qualquer historiador: como Montesquieu compreende o devir, isto é, por meio de que bases o autor justifica as transformações que, ao longo do tempo, se dão na esfera das sociedades? Já foi visto que Montesquieu expôs as estruturas ideais que deveriam existir nos diferentes tipos de governo e que se destinariam a mantê-los inalterados. Porém, sabe-se que todos os exemplos históricos analisados pelo autor estiveram sujeitos à mudança: o que pode explicá-lo? Ora, é justamente na noção de totalidade, importantíssima no pensamento de Montesquieu, que se deve encontrar a resposta a essa questão.

Em cada tipo de governo há uma totalidade formada pelos elementos correlacionados que se mencionou anteriormente. No núcleo dessa totalidade, contudo, reside a relação que é o próprio coração de um Estado, a saber, o binômio natureza/princípio. Ao ligar a república à virtude, a monarquia à honra e 0 despotismo ao medo, Montesquieu não apenas forneceu uma chave para 0 entendimento de por que os governos se mantêm, mas também dos motivos de suas transformações. Em um Estado ideal, a união da natureza com o princípio adequado faz com que as instituições, as leis e os costumes funcionem como partes uma máquina bem ajustada capaz de resistir melhor ao desgaste do tempo. Nesses casos, a permanência é o que prevalece. Entretanto, nos Estados empíricos nem sempre se verifica a união ideal, e é o descompasso entre natureza e princípio que conduz inexoravelmente às mudanças. Para Althusser, quando Montesquieu faz uso de exemplos impuros de governo (aqueles nos quais natureza e princípio não se coadunam), ele pretende demonstrar a unidade contraditória que os caracterizaria, e qual seria a própria causa interna de sua decadência. Assim sendo, percebe-se o quanto as Considerações são essenciais para a compreensão do pensamento histórico do autor, na medida em que trabalham sobre um exemplo concreto utilizando as ferramentas teóricas que seriam expostas mais explicitamente apenas em 0 espirito das leis. 
De fato, em seu estudo sobre os romanos, Montesquieu prima por mostrar que a grandeza deles foi a consequiência direta da harmonia entre seu regime político e seus costumes, ou, para ser mais exato, suas virtudes cívicas. 0 auge de Roma é apresentado pelo historiador como sendo o período republicano, tempo de liberdade para os cidadãos e de prosperidade para o Estado. Enquanto prevaleceu esse esquema harmônico, os romanos experimentaram o sucesso e a estabilidade de suas instituições. Mas, como foi visto, 0 desenvolvimento interno da sociedade romana gerou as sementes de sua própria decadência: a degeneração da virtude foi acompanhada pela corrupção do governo, e Roma tornou-se um império regido tiranicamente por seus líderes. Dessa maneira, por meio de um processo dialético, do interior de um Estado cuja totalidade constituía-se graças à relação república/virtude, formou-se a contradição capaz de arruiná-lo. A passagem do regime republicano ao imperial configura-se, portanto, como uma mudança histórica que deriva da natureza das coisas, na medida em que é impossível que um determinado governo persista no tempo sem que o princípio correto esteja a sustentá-lo. Tal é a idéia de Montesquieu ao afirmar que a corrupção de um governo começa quase sempre pela de seu princípio interno, pois nem a força das instituições, nem o poder das leis podem frear a decadência de um Estado que perdeu seus princípios. Diante disso, percebe-se a riqueza e a complexidade da interpretação histórica delineada por Montesquieu, interpretação na qual a política e as formulações jurídicas são de suma importância para se entender as razões que levam cada povo a ter seus períodos de estabilidade e de desequilibrio, ora mantendo seu modo de vida, ora passando por profundas transformações. Ao analisar esse duplo ol har da obra de Montesquieu, Althusser sintetizou muito bem sua originalidade por meio das seguintes palavras: "na profundidade destas inúmeras leis que passam e mudam, está portanto descoberta uma relação constante, que une a natureza ao princípio de um governo; e no âmago desta relação constante eis enunciada a variação interna da relação, a qual, fazendo passar a unidade da adequação à inadequação, da identidade à contradição, permite a inteligência das transformações e das revoluções nas totalidades concretas da história" ${ }^{24}$

Antes de concluir, é preciso ponderar, ainda, sobre certas críticas dirigidas a Montesquieu. Não obstante uma elaborada fundamentação conceitual e um espírito investigativo moderno animem o trabalho do autor, uma abordagem limitada pode dar uma falsa impressão de seu pensamento histórico. Collingwood, ${ }^{25}$ por exemplo, considerou

${ }^{24}$ ALthusser, L. Montesquieu: a política e a bistória. Lisboa: Editorial Presença; São Paulo: Martins Fontes, 1977. p. 69.

${ }^{25}$ Colungivood, R. G. A idéia de bistória. Lisboa: Presença, 1981. 
Montesquieu um historiador extremamente acrítico, cuja obra seguiria a tendência iluminista de apresentar a história passada como um jogo de forças irracionais. Além disso, Collingwood também pretende que Montesquieu teria defendido a idéia de que a explicação histórica deveria ser procurada nos fatos do mundo natural, tais como 0 clima, pois as instituições humanas surgiriam como efeitos necessários de causas naturais. Diante dessas afirmações, em primeiro lugar deve-se dizer que Collingwood comete um erro por haver restringido sua análise do trabalho do Montesquieu historiador à leitura de 0 espirito das leis. Essa obra constitui um estudo de teoria política do qual a História é inseparável, mas não é suficiente para se conhecer todas as facetas da concepção histórica do autor. Lendo-se também as Considerações, vê-se que, ao contrário de simplesmente buscar emitir julgamentos a posteriori sobre atos irracionais cometidos pelos romanos quando faziam sua própria história, Montesquieu dedicou-se a desvendar a dinâmica interna do desenvolvimento de Roma, sendo capaz de desenvolver uma perspectiva bem mais imparcial diante do passado do que grande parte de seus contemporâneos. E, em segundo lugar, Collingwood também se equivoca quando atribui aos processos naturais um papel tão determinante no conjunto das causas apontadas por Montesquieu para explicar as leis e as instituições humanas. Montesquieu apresenta uma teia realmente complexa de causalidade para lidar com a compreensão da história, de forma que os condicionantes naturais são apenas uma parte, embora muito importante, de um todo maior. Portanto, as Considerações não devem ser marginalizadas por quem deseja verdadeiramente conhecer a contribuição de Montesquieu ao pensamento histórico, sob pena de se emitir juízos incompletos e equivocados sobre o trabalho do escritor francês e de subestimar seus méritos. Elas são, junto com $O$ espírito das leis, a consumação de um elevado esforço de compreensão da história por meio da aliança entre problemas previamente formulados, teoria interpretativa, método e investigação empírica; enfim, tudo aquilo de que, mesmo nos dias de hoje, um historiador sério não pode prescindir. 